\title{
Flax yield potential as affected by irrigation intervals and nitrogen fertilizer rates
}

\author{
Khaled S. S. EL-Shimy **; Gaber. Y. M. Hammam*; Salah A. H. Allam*; Saber H. A. Mostafa** and \\ El-Saeed M. M. El-Gedwy* \\ *Agronomy Department, Faculty of Agriculture, Benha University \\ ** Fiber Crops Research Section, Field Crops Research Institute, Agricultural Research Center, Giza, \\ Egypt.
}

\begin{abstract}
Two field experiments were carried out at El-Gemmeiza Research Station, Gharbia Governorate, Agricultural Research Center, Egypt, during the two successive winter seasons of 2015/2016 and 2016/2017. The objective of this work was to evaluate the effect of irrigation intervals (every 21, 28 and 35 days) and nitrogen fertilizer rates [control (0), 30, 45 and $60 \mathrm{~kg} \mathrm{~N} / \mathrm{fad}$ ] on quantity and quality of straw and seed characters of flax (Variety Giza 10). The experimental design was split plot with three replications.

\section{The obtained results can be summarized as follows:-}

Obtained results indicate that significant differences in all studied traits among irrigation intervals in both seasons and combined analysis. Irrigated flax plants every 21 days gave the maximum values for plant height, technical length, straw yield/fad, fiber yield/fad, number of capsules/plant, number of seeds/capsule, seed yield/fad and oil yield/fad as well as gave the minimum values of fiber fineness (Nm). In contrast, irrigation every 35 days gave the minimum values for all studied characters under this study except, fiber fineness $(\mathrm{Nm})$. Irrigated flax every 28 days gain intermediate estimates in all studied traits without significance with irrigation every 21 days. All traits of flax under study, i.e. plant height, technical length, straw yield/fad, fiber yield/fad, number of capsules/plant, number of seeds/capsule, seed yield/fad and oil yield/fad showed significantly increased by increasing nitrogen fertilizer rates from 0 up to $60 \mathrm{~kg} \mathrm{~N} / \mathrm{fad}$, except fiber fineness (Nm) which decreased with increasing nitrogen rates in the both seasons and combined analysis. Results showed that irrigated flax plants every 21 days and soil fertilized with $60 \mathrm{~kg} \mathrm{~N} / \mathrm{fad}$ gave the maximum values of plant height and straw yield/fad only in the second season as well as seed and oil yields/fad in the two seasons and the combined. In addition to great reduction in fiber fineness had happened in this case. It could be summarized that irrigated flax plants (Giza 10) every 21 or 28 days and soil fertilized with $60 \mathrm{~kg} \mathrm{~N} /$ fad to maximized quantity and quality of straw and seed yield characters.
\end{abstract}

Keywords: Flax, irrigation intervals, nitrogen fertilizer rates.

\section{Introduction}

Flax is now unknown in the wild but originally it may have been a native of Asia. It has been cultivated since at least $5000 \mathrm{BC}$, probably first by the ancient Mesopotamians and later by the Egyptians who wrapped their mummies in linen cloth. The Romans spread flax cultivation to Northern Europe and now the plant is grown all over the world for the oil extracted from the seeds and for its fibers, which are made into linen and other cloths. Various parts of the plant have been used to make fabric, dye, paper, medicines, fishing nets, hair gels, and soap. It is also grown as an ornamental plant in gardens. The seeds are widely used medicinally. Their constituents include $30-40 \%$ of fatty oil (linseed oil) with esters of linoleic acid, linolenic acid, stearic acid and oleic acid; also mucilage, proteins, a cyanogenic glycoside (linamarin) and enzymes. Whole of crushed, the seeds are a reliable means of relieving constipation. Externally, crushed seeds mixed to a paste with water are used to make hot poultices to relieve pain and to heal septic wounds, skin rashes and ulcers. The extracted oil is used in the pharmaceutical industry to make liniments for burns and rheumatic pain. The oil is also important in the manufacture of paints, soap and printer's ink. In Egypt, flax (Linum usitatissimum, L.) is cultivated as a dual purpose (seeds for oil and stems for fibre). The cultivated area through the last 20 years was decreased from 60.000 to 30.000 faddans due to the great competition of other economic winter crops resulting in a gap between production and consumption. Therefore, it is necessary to increase flax productivity per unit area which could be achieved by using high yielding varieties and improving different agriculture treatments to gain highest yield characterize by best quality.

Alessi and Power (1970), Bauer and Frederick (1997) and Lisson and Mendham (2000) found that, irrigation increased flax straw and seed yield when precipitation was low and with poor distribution. Chorumale et al., (2001), Gabiana (2005), Gabiana et al., (2005) and Yenpreddiwar et al., (2007) mentioned that, two irrigations applied at flowering and capsule filling stages significantly increased the yield attributes, yield, oil content and 
oil yield of flax compared with no irrigation and irrigation at flowering stage only. In addition, Barky et al., (2012), Chavarria and Dos Santos (2012) Mirshekari et al., (2012) and Sharma et al., (2012) indicated that, irrigation at both 30 and 60 days after sowing (DAS) produced the highest values of growth characters compared with irrigation at 30 DAS only. Bauer et al., (2015) and Rashwan et al., (2016) illustrated that belonging irrigation interval on flax plants until 45 days gave minimum values for total plant height, seed yield/ha, oil yield/ha, straw yield /ha, fiber fineness, fiber yield/ha.

Determination of the required rate of nitrogen fertilizer of flax plants is the main important practices of great contribution for the highest production of better quality, as well as nitrogen is a key element for flax productivity as well as in many other field crops. Several investigations reported that increasing nitrogen fertilizer rates caused significant increase in all straw and seed characters of flax, Moawed and Abd El-Hamid (1999), El-Gazzar (2000), El-Shimy and Moawed (2000), Chorumale et al., (2001), Gabiana (2005), Gabiana et al., (2005), Moawed et al., (2008), Salim et al., (2008), Mousa et al., (2010), Sakandar et al., (2011), Khajani et al., (2012), Soethe et al., (2013), Kariuki et al., (2014), Rahimi (2014), El-Refaey et al., (2015) and El-Seidy et al., (2015).

Therefore, in the recent years many efforts were devoted to increase the productivity of the flax through improving genetic traits and use of improved cultivars which have high yields and high water use efficiency. The irrigation intervals and nitrogen fertilizer were considered two of the main factors that affecting directly the growth and productivity of flax plants. With keeping the above points in view, the objective of this research were to evaluate the performance and response of flax.

The main target of this investigation is to determine the suitable irrigation interval and optimum nitrogen fertilizer rate which achieve highest yield production from flax fiber and seeds in addition to their quality in farm of El-Gemmeiza Research Station, Gharbia Governorate.

\section{Materials and Methods}

Two field experiments were carried out at the Farm of El-Gemmeiza Research Station, Gharbia Governorate, Agricultural Research Center, Egypt, during the two successive winter seasons of $2015 / 2016$ and $2016 / 2017$. The aim of this study was to investigate the effect of irrigation intervals and nitrogen fertilizer rates on quantity and quality of straw and seed characters of flax (Variety Giza 10). Soil texture of the experimental site was clay-loam with $\mathrm{pH}$ nearly of 7.8. The physical and chemical properties of the experimental soil were determined according to the standard procedures described by Black (1965) and represented in Table, 1 in each of the two growing seasons.

Table 1. Chemical and mechanical properties of the experimental soil in the two growing seasons (2015/2016 and 2016/2017 seasons).

\begin{tabular}{lcc}
\hline \multirow{2}{*}{ Properties } & \multicolumn{2}{c}{ Seasons } \\
\cline { 2 - 3 } & \multicolumn{2}{c}{$2015 / 2016$} \\
\hline Ehemical analysis & 3.42 & 3.40 \\
\hline pH $(1: 2.5)$ & 7.9 & 7.7 \\
\hline CaCo3 \% & 1.9 & 2.1 \\
\hline O.M \% & 1.92 & 1.98 \\
\hline Total N (\%) & 0.10 & 0.12 \\
\hline Available N (ppm) & 27.08 & 31.93 \\
\hline Particle size distribution ( mechanical analysis ) & 8.1 \\
\hline Course sand \% & 9.2 & 19.2 \\
\hline Find sand \% & 18.4 & 26.5 \\
\hline Silt \% & 28.1 & 46.2 \\
\hline Clay \% & 44.3 & Clay-Loam \\
\hline Texture grade & Clay-Loam & \\
\hline
\end{tabular}

Each experiment included 12 treatments which were the combination of three irrigation interval and four nitrogen fertilizer rates.

Factors under study were as follows:

1. Three irrigation interval treatments, i.e. every 21, 28 and 35 days.

2. Four nitrogen fertilizer rates, i.e. control (0), 30, 45 and $60 \mathrm{~kg} \mathrm{~N} / \mathrm{fad}$, nitrogen fertilizer was applied in form of urea $(46 \% \mathrm{~N})$, and divided into two equal parts and applied before the first and second irrigation in each season.

Seeds of flax cv. Giza 10 (a fiber type) were obtained from Fiber Crops Research Section, Field Crops Research Institute, Agricultural Research Center, Giza, Egypt. The experimental design was split plot in three replications. The three irrigation intervals treatments were distributed in the main 
plots, whereas the four nitrogen fertilizer rates were arranged at random in sub plots. The preceding summer crop in the two seasons was rice crop. The sub plot area was $21 \mathrm{~m}^{2}$ (4 X $\left.5.25 \mathrm{~m}\right)$. Experiments were planted on November $1^{\text {th }}$ and $7^{\text {th }}$ in the first and the second seasons, respectively. Seeds were broadcasting at the rate of $60 \mathrm{~kg}$ seeds / fad. Phosphorous fertilizer was applied in form of Calcium super phosphate $\left(12.5 \% \mathrm{P}_{2} \mathrm{O}_{5}\right)$ at a rate of $100 \mathrm{~kg} /$ fad during soil preparation in each season. The other recommended agronomic practices of growing flax were applied in the manner prevailing in the region were practiced.

\section{Data recorded:}

At maturity, about 150 days from sowing date, ten guarded plants were taken randomly from each sub plot for recording the following plant traits, in addition to straw, fiber and seed yields/fad (estimated according to yield from one meter square of each sub plot). After harvesting and removing the capsules from plants of each subplot, retting process took place at Fiber Crops Research Section, El-Gemmeiza Agriculture Research Station. Straw of each sub plot was arranged in bundles and put in retting basins and soaked in water for about 12 hours. After soaking, the water was changed to leach out all the soluble materials. Retting period was about one week in summer season. The degree of water temperature during retting process ranged from 28 to $32^{\circ} \mathrm{C}$ and the acidity was $\mathrm{pH}$ 6-7. The retted straw was washed with water and finally dried in open air. Thus, the fibers were easily extracted from above the woody part of the stem. The recorded characters included:

A- Straw yield and related characters:

1- Plant height $(\mathrm{cm})$. From the cotyledonary node till the top of the plant.

2- Technical length of the main stem $(\mathrm{cm})$. From the cotyledonary node till the beginning of apical branching zone of the main stem.

3- Straw yield (ton/fad). It was estimated according to weight of air dried straw yield $/ 1 \mathrm{~m}^{2}$ of each sub-plot.

4- $\quad$ Fiber yield ( $\mathrm{kg} / \mathrm{fad})$. It was estimated according to fiber yield/1 m2 of each sub-plot.

Fiber yield $=$ Straw yield $X$ Fiber $\%$.

Fiber $\%=$ Fiber yield after retting/ Straw yield after retting for each sub plot $X \mathbf{1 0 0}$.

5- $\quad$ Fiber fineness $(\mathrm{Nm})$. It was calculated according to Radwan and Momtaz (1966),

Fiber fineness $=($ No. of 20 fibers $X$ Length of fibers / weight of fibers in $\mathrm{mg}$ ).

B- Seed yield and related characters:

6- Number of capsules/plant.

7- Number of seeds/capsule. Which recorded on 5 random capsules from each sub-plot

8- $\quad$ Seed yield $(\mathrm{kg} / \mathrm{fad})$. It was estimated according to seed yield $/ 1 \mathrm{~m}^{2}$ of each sub plot.

9- $\quad$ Oil yield $(\mathrm{kg} / \mathrm{fad})$. It was calculated by multiplying seed oil \% $\mathrm{X}$ seed yield/fad. Oil percentage (\%). It was determined as described by the (A.O.A.C., 1990) methods, using petroleum ether $\left(40-60{ }^{\circ} \mathrm{C}\right)$ in Soxhlet apparatus.

\section{Statistical analysis:}

The analysis of variance was carried out according to the procedure described by Gomez and Gomez (1984). Data were statistically analyzed for each season and the homogeneity of experimental error, in both seasons, was tested. Then, the combined analysis of the two seasons was done according to using the MSTAT-C Statistical Software Package (Michigan State University, 1983). L. S. D. test at 0.05 level was used to compare among treatments.

\section{Results and Discussion}

\section{A- Straw yield and related characters:}

Mean values of straw characters for flax variety Giza 10 as affected by irrigation intervals and nitrogen fertilizer rates in 2015/2016, 2016/2017 and combined analysis are presented in Table 2.

Data obtained revealed that all five straw traits significantly differed in the first and second seasons as well as the combined over them concerning the two studied factors i.e., irrigation intervals and nitrogen rates. Regarding irrigation intervals effect in the combine results, irrigated flax plants at the shortest intervals (21 days) achieved maximum estimates in plant height, technical length, straw yield/fad and fiber yield/fad. In the same time, fiber fineness character was in the opposite direction. By means that more amount of water which added to plants at the shortest interval caused more coarse fiber and decrease fiber fineness $(\mathrm{Nm})$ in comparison with the longest irrigation one. This behavior may be due to deposit more cellulosic layers on the primary wall inside to make secondary cell wall as resulting to more solvent nutrients from the soil. The differences between irrigation at 21 days and 28 days did not reach the level of significance in all straw characters. The results obtained from the combined over both seasons, the superiority ratios between irrigation at 21 days and either 28 or 35 days were 6.18 and $11.69 \%$ for plant height; 5.84 and $11.70 \%$ for technical length; 8.36 and $17.75 \%$ for straw yield ton/fad in addition to 5.55 and $11.39 \%$ for fiber yield $\mathrm{kg} / \mathrm{fad}$. Meanwhile, the superiority percentage between fiber fineness estimates which irrigated every 35 days and each of 28 and 21 days were 6.06 and $7.01 \%$, respectively. Many investigators came out with similar results as Alessi and Power (1970), Bauer and Frederick (1997) and Lisson and Mendham (2000), Chorumale et al., (2001), Gabiana (2005), Gabiana et al., (2005) and Yenpreddiwar et al., (2007), Barky et al., (2012), Chavarria and Dos Santos (2012), Mirshekari et al., (2012), Sharma et al., (2012), Bauer et al., (2015) and Rashwan et al., (2016). 
Table 2. Mean values of some straw characters for the flax variety Giza 10 as affected by irrigation intervals and nitrogen fertilizer rates in $2015 / 2016$, 2016/2017 seasons and combined analysis.

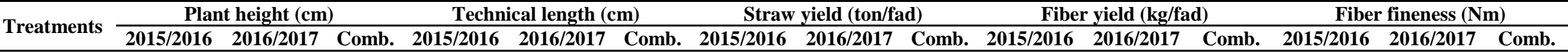
Irrigation intervals

\begin{tabular}{|c|c|c|c|c|c|c|c|c|c|c|c|c|c|c|c|c|}
\hline \multicolumn{2}{|c|}{21 days } & 120.71 & 121.83 & 121.27 & 109.02 & 108.48 & 108.75 & 4.788 & 4.807 & 4.797 & 707.585 & 722.090 & 714.838 & $\mathbf{1 7 9 . 2 3 7}$ & 182.605 & 180.921 \\
\hline \multicolumn{2}{|c|}{28 days } & $\mathbf{1 1 3 . 4 3}$ & 115.00 & 114.21 & 103.02 & 102.46 & 102.75 & 4.395 & 4.457 & 4.427 & 663.718 & 690.778 & 677.245 & 181.283 & 183.798 & 182.541 \\
\hline \multicolumn{2}{|c|}{35 days } & 106.88 & 110.28 & 108.58 & 96.20 & 98.52 & 97.36 & 3.891 & 4.258 & 4.074 & 631.055 & 652.398 & 641.725 & 192.397 & 194.801 & 193.598 \\
\hline \multicolumn{2}{|c|}{ L.S.D. at 5\% } & $\mathbf{7 . 4 6}$ & 7.13 & 9.76 & 6.38 & 6.72 & 9.11 & 0.640 & 0.300 & 0.440 & 45.880 & $\mathbf{3 7 . 3 2 0}$ & 40.520 & 4.6 & 2.7 & 5.2 \\
\hline \multicolumn{17}{|c|}{ Nitrogen fertilizer rates } \\
\hline \multicolumn{2}{|c|}{ Control (0) } & 107.21 & 108.80 & 108.01 & 99.06 & 98.60 & 98.83 & 3.983 & 4.065 & 4.024 & 594.290 & 643.893 & 619.092 & 193.178 & 196.202 & 194.690 \\
\hline \multicolumn{2}{|c|}{$30 \mathrm{~kg}$ N/fad } & 109.29 & 112.50 & 110.90 & 100.88 & 100.91 & 100.90 & 4.310 & 4.311 & 4.310 & 640.470 & 646.097 & 643.283 & 188.191 & 190.118 & 189.154 \\
\hline \multicolumn{2}{|c|}{$45 \mathrm{~kg} \mathrm{~N} / \mathrm{fad}$} & 117.21 & 118.84 & 118.03 & 104.22 & 105.56 & 104.89 & 4.518 & 4.728 & 4.623 & 700.893 & 712.127 & 706.510 & 182.230 & 184.808 & 183.519 \\
\hline \multicolumn{2}{|c|}{$60 \mathrm{~kg} \mathrm{~N} / \mathrm{fad}$} & 120.97 & 122.66 & 121.82 & 106.82 & 107.54 & 107.18 & 4.620 & 4.926 & 4.773 & 734.157 & 751.570 & 742.863 & 173.623 & $\mathbf{1 7 7 . 1 4 5}$ & $\mathbf{1 7 5 . 3 8 4}$ \\
\hline \multicolumn{2}{|c|}{ L.S.D. at 5\% } & 4.21 & 4.09 & 4.12 & 2.99 & 2.14 & 2.85 & 0.300 & 0.300 & 0.440 & 36.260 & 42.450 & 39.240 & 4.6 & 4.2 & 4.8 \\
\hline \multicolumn{17}{|c|}{ The interaction effect between irrigation intervals and nitrogen fertilizer rates } \\
\hline \multirow{4}{*}{$\begin{array}{c}21 \\
\text { days }\end{array}$} & $\mathbf{0}$ & 111.97 & 112.78 & 112.38 & 103.94 & 101.67 & 102.81 & 4.189 & 4.264 & 4.227 & 630.340 & 650.650 & 640.495 & $\mathbf{1 8 9 . 7 8 3}$ & 192.580 & 191.182 \\
\hline & 30 & 114.53 & 116.72 & 115.63 & 105.35 & 105.58 & 105.47 & 4.669 & 4.562 & 4.616 & 669.690 & 682.830 & 676.260 & 183.155 & 186.133 & 184.644 \\
\hline & 45 & 126.50 & 126.78 & 126.64 & 111.84 & 112.03 & 111.94 & 5.131 & 5.123 & 5.127 & 748.420 & 765.400 & 756.910 & 180.368 & 183.845 & 182.107 \\
\hline & 60 & $\mathbf{1 2 9 . 8 5}$ & 131.02 & 130.44 & 114.96 & 114.63 & 114.80 & 5.161 & 5.277 & 5.219 & $\mathbf{7 8 1 . 8 9 0}$ & $\mathbf{7 8 9 . 4 8 0}$ & $\mathbf{7 8 5 . 6 8 5}$ & 163.643 & 167.862 & 165.753 \\
\hline \multirow{4}{*}{$\begin{array}{c}28 \\
\text { days }\end{array}$} & $\mathbf{0}$ & $\mathbf{1 0 7 . 3 3}$ & 108.65 & 107.99 & 99.01 & 98.93 & 98.97 & 4.057 & 4.071 & 4.064 & $\mathbf{5 8 6 . 9 4 0}$ & 621.750 & 604.345 & 192.858 & 197.178 & 195.018 \\
\hline & 30 & 109.42 & 112.54 & 110.98 & 102.80 & 100.76 & 101.78 & 4.429 & 4.228 & 4.329 & 640.780 & 655.930 & 648.355 & $\mathbf{1 8 7 . 5 2 8}$ & 188.162 & 187.845 \\
\hline & 45 & 115.92 & 117.39 & 116.66 & 103.53 & 104.40 & 103.97 & 4.561 & 4.677 & 4.619 & 691.850 & 719.900 & 705.875 & 175.090 & 176.903 & 175.997 \\
\hline & 60 & 121.03 & 121.42 & 121.23 & 106.73 & 105.75 & 106.24 & 4.534 & 4.853 & 4.694 & 735.300 & 765.530 & 750.415 & 169.657 & 172.950 & $\mathbf{1 7 1 . 3 0 4}$ \\
\hline \multirow{4}{*}{$\begin{array}{c}35 \\
\text { days }\end{array}$} & $\mathbf{0}$ & 102.32 & 104.98 & 103.65 & 94.23 & 95.20 & 94.72 & 3.702 & 3.859 & 3.781 & 565.590 & 659.280 & 612.435 & 196.893 & 198.848 & 197.871 \\
\hline & 30 & 103.93 & 108.23 & 106.08 & 94.50 & 96.40 & 95.45 & 3.831 & 4.142 & 3.987 & 610.940 & $\mathbf{5 9 9 . 5 3 0}$ & 605.235 & 193.890 & 196.058 & 194.974 \\
\hline & 45 & 109.22 & 112.36 & 110.79 & 97.30 & 100.26 & 98.78 & 3.863 & 4.384 & 4.124 & 662.410 & 651.080 & 656.745 & 191.233 & 193.675 & 192.454 \\
\hline & 60 & 112.03 & 115.55 & 113.79 & 98.78 & 102.23 & 100.51 & 4.166 & 4.648 & 4.407 & 685.280 & 699.700 & 692.490 & 187.570 & 190.622 & 189.096 \\
\hline \multicolumn{2}{|c|}{ L.S.D. at 5\% } & N.S. & N.S. & N.S. & N.S. & 3.71 & N.S. & N.S. & 0.520 & N.S. & N.S. & N.S. & N.S. & 8.0 & 7.3 & 8.3 \\
\hline
\end{tabular}


Results indicated that increasing nitrogen fertilizer rates from the untreated control (0) up to 60 $\mathrm{kg} \mathrm{N} /$ fad caused remarkable increments in the four straw characters i.e., plant height, technical length, straw yield ton/fad and fiber yield $\mathrm{kg} / \mathrm{fad}$ in the first and second seasons as well as in the combined over them. The superiority rations in the combined analysis between the highest nitrogen rate $(60 \mathrm{~kg}$ $\mathrm{N} /$ fad) and each of 45, 30 and $0 \mathrm{~kg} \mathrm{~N} /$ fad were 3.21 , 9.85 and $12.79 \%$ for plant height; 2.18, 6.22 and $8.45 \%$ for technical length; 3.24, 10.74 and $18.61 \%$ for straw yield/fad in addition to 5.15, 15.48 and $19.99 \%$ for fiber yield ton/fad, respectively. Meanwhile, increase nitrogen rate caused more coarse fiber, by means that more fine fiber obtained from the untreated control $(0 \mathrm{~kg} \mathrm{~N} / \mathrm{fad})$. The estimates of fiber fineness from the combined were $195 \mathrm{Nm}$ for the control, $189 \mathrm{Nm}$ for added $30 \mathrm{~kg}$ $\mathrm{N} /$ fad, $184 \mathrm{Nm}$ from the nitrogen rate $45 \mathrm{~kg} / \mathrm{fad}$ and $175 \mathrm{Nm}$ for applying $60 \mathrm{~kg} \mathrm{~N} / \mathrm{fad}$. The superiority ratios between the control $(0)$ and each of added 30 , 45 and $60 \mathrm{~kg} \mathrm{~N} /$ fad were 2.93, 6.09 and $11.01 \%$, respectively. Similar results were also obtained by Moawed and Abd El-Hamid (1999), El-Gazzar (2000), El-Shimy and Moawed (2000), Chorumale et al., (2001), Gabiana (2005), Gabiana et al., (2005), Moawed et al., (2008), Salim et al., (2008), Mousa et al., (2010), Sakandar et al., (2011), Khajani et al., (2012), Soethe et al., (2013), Kariuki et al., (2014), Rahimi (2014), El-Refaey et al., (2015) and El-Seidy et al., (2015).

The interaction effect between irrigation intervals and nitrogen fertilizer rates had significant effect on technical length and straw yield ton/fad only in the second season, while it was significant in both seasons and the combined in fiber fineness character. Similar results were also obtained by Chorumale et al., (2001), Gabiana (2005), Gabiana et al., (2005) and Ibrahim (2009).

\section{B- Seed yield and related characters:}

From Table 3, results showed significant differences between each of either irrigation intervals or nitrogen fertilizer rates in seed characters i.e., number of capsules/plant, number of seeds/capsule, seed yield/fad and oil yield/fad in the both seasons and combined analysis.
Irrigated flax plants every 21 days achieved an increment in all four seed characters under study. The superiority ratios between irrigation at 21 days and each of 28 and 35 days in combined analysis were 9.87 and $22.13 \%$ for No. of capsules/plant; 3.43 and $3.22 \%$ for No. of seeds/capsule; 5.72 and $9.40 \%$ for seed yield/fad in addition to 9.70 and $18.99 \%$ for oil yield/fad. Similar results were also obtained by Alessi and Power (1970), Bauer and Frederick (1997) and Lisson and Mendham (2000), Chorumale et al., (2001), Gabiana (2005), Gabiana et al., (2005) and Yenpreddiwar et al., (2007), Barky et al., (2012), Chavarria and Dos Santos (2012), Mirshekari et al., (2012), Sharma et al., (2012), Bauer et al., (2015) and Rashwan et al., (2016).

In relation to nitrogen fertilizer rates effect, the seed traits illustrated clear increments in these characters with increasing nitrogen rate up to 60 $\mathrm{kg} / \mathrm{fad}$ without significance with applying $45 \mathrm{~kg}$ $\mathrm{N} / \mathrm{fad}$ in both seasons and combined analysis. The superiority percentages between added the highest dose (60 kg N/fad) and each of 45, $30 \mathrm{~kg} \mathrm{~N} / \mathrm{fad}$ and 0 (control) in combined analysis were 6.35, 25.34 and $44.76 \%$ for No. of capsules/plant; 1.01, 2.83 and $7.55 \%$ for No. of seeds/capsule; 6.74, 10.78 and $14.43 \% \%$ for seed yield/fad in addition to 10.69 , 19.48 and $27.41 \%$ for oil yield/fad. Many investigators came out with similar results as Moawed and Abd El-Hamid (1999), El-Gazzar (2000), El-Shimy and Moawed (2000), Chorumale et al., (2001), Gabiana (2005), Gabiana et al., (2005), Moawed et al., (2008), Salim et al., (2008), Mousa et al., (2010), Sakandar et al., (2011), Khajani et al., (2012), Soethe et al., (2013), Kariuki et al., (2014), Rahimi (2014), El-Refaey et al., (2015) and El-Seidy et al., (2015).

The interaction between irrigation intervals and nitrogen fertilizer rates had significant effect on seed and oil yields/fad in the two seasons and the combined, by means that dependent effect was found concerning the two studied factors in this case. Similar results were also obtained by Chorumale $\boldsymbol{e t}$ al., (2001), Gabiana (2005), Gabiana et al., (2005) and Ibrahim (2009). 
Table 3. Mean values of some seed characters for the flax variety Giza 10 as affected by irrigation intervals and nitrogen fertilizer rates in $2015 / 2016$, 2016/2017 seasons and combined analysis.

\begin{tabular}{|c|c|c|c|c|c|c|c|c|c|c|c|c|c|}
\hline \multirow{2}{*}{\multicolumn{2}{|c|}{ Treatments }} & \multicolumn{3}{|c|}{ Number of capsules/plant } & \multicolumn{3}{|c|}{ Number of seeds/ capsule } & \multicolumn{3}{|c|}{ Seed yield $(\mathrm{kg} / \mathrm{fad})$} & \multicolumn{3}{|c|}{ Oil yield (kg/fad) } \\
\hline & & $2015 / 2016$ & $2016 / 2017$ & Comb. & $2015 / 2016$ & $2016 / 2017$ & Comb. & $2015 / 2016$ & $2016 / 2017$ & Comb. & $2015 / 2016$ & $2016 / 2017$ & Comb. \\
\hline \multicolumn{14}{|c|}{ Irrigation intervals } \\
\hline \multicolumn{2}{|c|}{21 days } & 10.413 & 10.855 & 10.635 & 7.363 & 7.595 & 7.478 & 500.468 & 478.016 & 489.242 & 169.192 & 167.329 & 169.261 \\
\hline \multicolumn{2}{|c|}{28 days } & 9.198 & 10.165 & 9.680 & 7.303 & 7.158 & 7.230 & 465.592 & 459.921 & 462.757 & 151.604 & 156.978 & $\mathbf{1 5 4 . 2 9 1}$ \\
\hline \multicolumn{2}{|c|}{35 days } & 8.173 & 9.250 & 8.708 & 7.148 & 7.340 & 7.245 & 447.157 & 447.279 & 447.218 & 140.091 & 144.405 & 142.248 \\
\hline \multicolumn{2}{|c|}{ L.S.D. at 5\% } & 1.74 & 1.48 & 1.65 & 0.16 & 0.19 & 0.17 & 37.500 & 28.640 & 29.700 & 22.110 & 17.620 & 23.810 \\
\hline \multicolumn{14}{|c|}{ Nitrogen fertilizer rates } \\
\hline \multicolumn{2}{|c|}{ Control (0) } & 7.880 & 7.713 & 7.797 & 7.050 & 6.933 & 6.992 & 439.344 & 438.756 & 439.050 & 134.509 & 141.448 & $\mathbf{1 3 7 . 9 7 8}$ \\
\hline \multicolumn{2}{|c|}{$30 \mathrm{~kg}$ N/fad } & 8.390 & 9.620 & 9.005 & 7.197 & 7.430 & 7.313 & 457.716 & 449.294 & 453.505 & 145.218 & 149.046 & 147.132 \\
\hline \multicolumn{2}{|c|}{$45 \mathrm{~kg}$ N/fad } & 9.910 & 11.317 & 10.613 & 7.397 & 7.493 & 7.445 & 471.700 & 469.625 & 470.663 & 156.797 & 160.851 & $\mathbf{1 5 8 . 8 2 4}$ \\
\hline \multirow{2}{*}{\multicolumn{2}{|c|}{$60 \mathrm{~kg} \mathrm{~N} / \mathrm{fad}$}} & 10.863 & 11.710 & 11.287 & 7.440 & 7.600 & 7.520 & 515.530 & 489.278 & 502.404 & 177.992 & 173.604 & $\mathbf{1 7 5 . 7 9 8}$ \\
\hline & & 1.86 & 1.67 & 1.83 & 0.18 & 0.14 & 0.18 & 52.180 & 32.020 & 36.650 & 31.490 & 24.150 & 29.720 \\
\hline \multicolumn{14}{|c|}{ The interaction effect between irrigation intervals and nitrogen fertilizer rates } \\
\hline \multirow{4}{*}{21 days } & $\mathbf{0}$ & 8.830 & 8.440 & 8.635 & 7.120 & 7.350 & 7.235 & 456.228 & 449.178 & 452.703 & 146.542 & 151.285 & $\mathbf{1 4 8 . 9 1 4}$ \\
\hline & 30 & 9.230 & 10.350 & 9.790 & 7.280 & 7.590 & 7.435 & 466.960 & 464.920 & 465.940 & 156.582 & 159.003 & $\mathbf{1 5 7 . 7 9 3}$ \\
\hline & 45 & 11.380 & 12.040 & 11.710 & 7.570 & 7.640 & 7.605 & 482.688 & 492.000 & 487.344 & 161.005 & $\mathbf{1 7 5 . 2 5 0}$ & 168.128 \\
\hline & 60 & 12.210 & 12.590 & 12.400 & 7.480 & 7.800 & 7.640 & 595.997 & 505.965 & 550.981 & 212.640 & $\mathbf{1 8 3 . 7 7 7}$ & 198.209 \\
\hline \multirow{4}{*}{28 days } & $\mathbf{0}$ & 7.810 & 7.500 & 7.655 & 7.110 & 6.250 & 6.680 & 436.152 & 436.697 & 436.425 & 131.347 & 142.165 & 136.756 \\
\hline & 30 & 8.290 & 9.900 & 9.095 & 7.240 & 7.430 & 7.335 & 462.702 & 450.868 & 456.785 & 143.100 & 152.397 & 147.749 \\
\hline & 45 & 9.990 & 11.570 & 10.780 & 7.390 & 7.450 & 7.420 & 478.588 & 459.063 & 468.826 & 162.597 & $\mathbf{1 5 8 . 5 6 3}$ & $\mathbf{1 6 0 . 5 8 0}$ \\
\hline & 60 & 10.700 & 11.690 & 11.195 & 7.470 & 7.500 & 7.485 & 484.927 & 493.055 & 488.991 & $\mathbf{1 6 9 . 3 7 0}$ & 174.787 & $\mathbf{1 7 2 . 0 7 9}$ \\
\hline \multirow{5}{*}{35 days } & $\mathbf{0}$ & 7.000 & 7.200 & 7.100 & 6.920 & 7.200 & 7.060 & 425.652 & $4 \mathbf{4 3 0 . 3 9 3}$ & 428.023 & 125.637 & 130.893 & 128.265 \\
\hline & 30 & 7.650 & 8.610 & 8.130 & 7.070 & 7.270 & 7.170 & 443.487 & 432.095 & 437.791 & $\mathbf{1 3 5 . 9 7 2}$ & 135.737 & $\mathbf{1 3 5 . 8 5 5}$ \\
\hline & 45 & 8.360 & 10.340 & 9.350 & 7.230 & 7.390 & 7.310 & 453.823 & 457.813 & 455.818 & 146.790 & 148.740 & 147.765 \\
\hline & 60 & 9.680 & 10.850 & 10.265 & 7.370 & 7.500 & 7.435 & 465.667 & 468.813 & 467.240 & 151.965 & 162.248 & 157.107 \\
\hline & L.S.D. at 5\% & N.S. & N.S. & N.S. & N.S. & N.S. & N.S. & 90.376 & 55.459 & 63.478 & 54.541 & 41.828 & 51.475 \\
\hline
\end{tabular}




\section{Conclusion}

Generally, it could be concluded that flax plants need the water for cell division, elongation, photosynthesis, bio processes in cytoplasm, transfer and distribution of carbohydrate, hormones and minerals salts. Moreover, flax plants at short irrigation interval (every 21 days) achieved an increment in majority characters, except fiber fineness of flax which take the opposite trend and consequently coarse fiber. In the same time, increasing nitrogen rates encourage vegetative plant growth, which return back for increasing plant yield, look for also exception in fiber fineness that more nitrogen amount caused more coarse fiber. It could be summarized that irrigated flax plants (Giza 10) every 21 days and soil fertilized with $60 \mathrm{~kg} \mathrm{~N} /$ fad to maximized quantity and quality of straw and seed yield characters.

\section{Acknowledgement}

The authors thank Prof. Dr. Gamal El-Din ElShimy and Prof. Dr. Saeed Zedan Professors in Fiber Crops Res. Sec., Field Crops Res. Inst., Agric. Res. Center, Dokki, Giza, Egypt, for reviewing and helpful comments regarding a previous draft of the manuscript. The field staff of Agronomy Department, Faculty of Agriculture at Moshtohor, Benha University is gratefully acknowledged.

\section{References}

A.O.A.C. (1990). Official methods of analysis association of official analysis chemists, $13^{\text {th }} \mathrm{Ed}$., Washington, D. C., U. S. A.

Alessi, J. and J. F. Power (1970). Influence of row spacing, irrigation, and weeds on dry land flax yield, quality, and water use. Agron. J., 62, 635637.

Barky, A. B.; D. M. El-Hariri; Sh. S. Mervat and H. M. S. El-Bassiouny (2012). Drought stress mitigation by foliar application of salicylic acid in two linseed varieties grown under newly reclaimed sandy soils. J. Appl. Sci. Res., 8 (7): 3503-3514.

Bauer, P. J. and J. R. Frederick (1997). Winter crop effect on double-cropped cotton grown with and without irrigation. In R. N. Gallaher \& R. McSorley (Eds.), Proc. of the $20^{\text {th }}$ Ann. Southern Conservation Tillage Conf. for Sustainable Agric., June 24-26, 1997, University of Florida Special Series SS-AGR-60 (pp. 220-222).

Bauer, Ph. J.; K. C. Stone; J. A. Foulk and R. B. Dodd (2015). Irrigation and cultivar effect on flax fiber and seed yield in the Southeast USA. Industrial Crops and Products, 67:7-10.

Black, C.A., (1965). Methods of Soil Analysis. Amer. Soc. of Agronomy, Inc. Pub. Madison, Wisconsin, USA.
Chavarria, G. and H. P. Dos Santos (2012). Plant Water Relations: Absorption, Transport and Control Mechanisms, Advances in Selected Plant Physiology Aspects. In G. Montanaro (Ed.), InTech.

Chorumale, P. B.; B. N., Dahatonde and J. S. Vyas (2001). Response of linseed to nitrogen under varied moisture regimes. Ann. Plant Physiol., 13 (2):192-194.

El-Gazzar, A. A. M. (2000). Effect of nitrogen rates and some N-biofertilizer sources on growth, yield and quality of flax. Alex. Sci. Exch., 21 (4): 281 292.

El-Refaey, R. A.; E. H. El-Seidy; T. A. AbouZaied; U. A. Abd El-Razek and E. A. Rashwan (2015). Effect of different mineral and biological nitrogenous fertilizers combinations on straw yield and fiber quality of some flax (Linum usitatissimum L.) genotypes. Glob. J. Agric. Food Safety Sci., 2 (3): 346-364.

El-Seidy, E. H.; R. A. El-Refaey; T. A. AbouZaied; U. A. Abd El-Razek and E. A. Rashwan (2015). effect of different mineral and biological nitrogenous fertilizers combinations on seed yield and its components of some flax (Linum usitatissimum L.) genotypes. Glob. J. Agric. Food Safety Sci., 2 (3): 365-383.

El-Shimy, G. H. and E. A. Moawed (2000). Effect of different potassium and nitrogen fertilizer levels on Giza 8 and Viking flax varieties. J. Agric. Sci. Mansoura Univ., 25 (1): 5993-6007.

Gabiana, C. P. (2005). Response of linseed (Linum usitatissimum L.) to irrigation, nitrogen and plant population. M.Sc. Thesis, Fac. Sci., Lincoln Univ., New Zealand.

Gabiana, C.; B. A. McKenzie and G. D. Hill (2005). The influence of plant population, nitrogen and irrigation on yield and yield components of linseed. Agronomy N.Z., 35: 4456.

Gomez, K.A. and A.A. Gomez, (1984). Statistical procedures for agricultural research. $2^{\text {nd }}$, (ed). John Wiley and Sons, NY, U.S.A.

Ibrahim, H. M. (2009). Effect of sowing date and $\mathrm{N}$-fertilizer levels on seed yield, some yield components and oil content in flax. Alex. J. Agric. Res., 54 (1): 19-28.

Kariuki, L.W.; P. W. Masinde; A. N. Onyango; S. M. Githiri and K.Ogila (2014). The growth and seed yield of five linseed (Linum usitatissimumL.) varieties as influenced by nitrogen application. J. Animal and Plant Sc., 22 (3): 3493-3509

Khajani, F. P.; H. Irannezhad; M. Majidian and H. Draki (2012). Influence of different levels of nitrogen, phosphorus and potassium on yield and yield components of flax seed oil (Linum usitatissimum L.) variety. Lirina J. of medicinal plants Res., 6 (6): 1050-1054. 
Lisson, S. N. and J. J. Mendham (2000). Agronomic studies of flax (Linum usitatissimum, L.) in south-eastern Australia. Aust. J. Exp. Agric., 40 :1101-1112.

Michigan State University (1983). MSTAT-C: Micro-computer Statistical Program, Version 2. Michigan State University, East Lansing.

Mirshekari, M.; R. Amiri; H. Nezhad; S. A. S. Noori and O.R. Zandvakili (2012). Effects of planting date and water deficit on quantitative and qualitative traits of flax seed. AmericanEurasian J. Agric. Environ. Sci., 12 (7): 901-913.

Moawed, E. A. and S. Z. Abd El-Hamid (1999). Response of some local and introduced flax (Linum usitatissimum, L.) cultivars to various nitrogen fertilization levels. Egypt J. Appl. Sci., 14 (12): 518-540.

Moawed, E.A.; M.M.M. Hussein; and E.E.M. Lotfy (2008). Effect of nitrogen fertilizer levels and biofertilization on yield and quality of two new flax varieties under saline soil conditions. Annals of Agric. Sc., Moshtohor, 46 (2):105-112

Mousa, M.A.; E. A. E. El-Kady and Z. S. Zedan (2010). Effect of nitrogen fertilizers and some micro-nutrients on flax yield and chemical composition characters. J. Plant Production, Mansoura Univ., 1 (5): 713-720.

Radwan, S. R. H.; and A. Momtaz (1966). The technological properties of flax fibers and the methods of estimating them. El- Falaha J., 46 (5) :466-476.
Rahimi, M. M. (2014). Effect of sowing date and nitrogen on yield and yield components of medicinal flax. Int. J. Biosci., 5 (12): 160-165.

Rashwan, E.; A. Mousa; A. El-Sabagh and C. Barutcular (2016). Yield and quality traits of some flax cultivars as influenced by different irrigation intervals. J. Agric. Sci., 8 (10): 226240.

Sakandar, A.; M. A. Cheema; M.A., Wahid; A. Sattar and A.F. Saleem (2011). Comparative production potential of linola and linseed under different nitrogen levels. Crop and Environment. 2 (2):33-36.

Salim, M.S.; T.A. Abou Zaid; A. M. Abdallah and A. M. Mousa (2008). Effect of nitrogen fertilization level and foliar application some nutrient compounds on some flax verities. Egypt. J. Appl. Sci., 23 (3).

Sharma, G.; R. Sutalya; S. Prasad and I. Sharma (2012). Effect of irrigation and intercropping system on growth, yield and quality of mustered and linseed. Crop Res. Hisar., 25 (3), 579-581.

Soethe, G.; A. Feiden; D. Bassegio; R. F. Santos; S. N. M. de Souza and D. Secco (2013). Sources and rates of nitrogen in the cultivation of flax. Afr. J. Agric. Res., 8 (19): 2249-2254.

Yenpreddiwar, M. D.; R. R. Nikam; N. G. Thakre; K. Harsha and S. K. Sharma (2007). Effect of irrigation and moisture conservation practices on yield of linseed. J. Soils Crops, 17 (1): 121-127.

$$
\begin{aligned}
& \text { الكفاءة الإنتاجية لمحصول الكتان تحت تأثير فترات الري ومستويات السماد النيتروجيني } \\
& \text { خالد شعبان سيد الثيمي** ـ جابر يحيى محد همام * ـ صلاح عباس حسن علام* ـ صابر حسين أحمد مصطفى** ـ السعيد محمد محمود الجدوي* }
\end{aligned}
$$

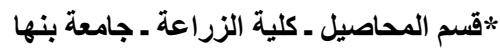

$$
\begin{aligned}
& \text { ** قسم بحوث الألياف ـ معه بحوث المحاصيل الحقلية ـ مركز البحوث ـ بامعة الزراعيةـ جيزة ـ القاهرة }
\end{aligned}
$$

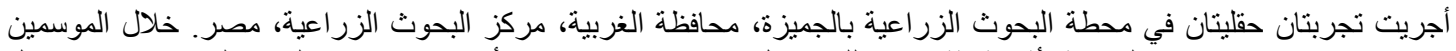

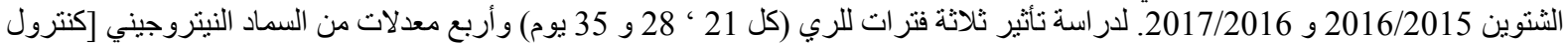

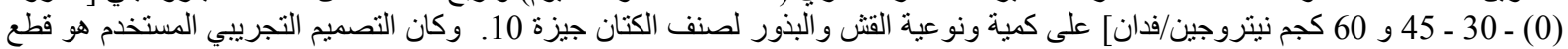



$$
\begin{aligned}
& \text { ويمكن تلخيص أهم النتائج فيما يلي:- }
\end{aligned}
$$

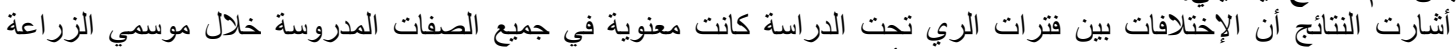

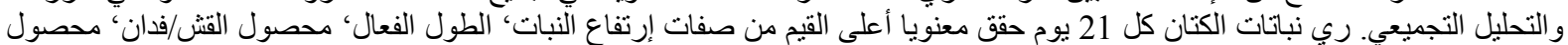

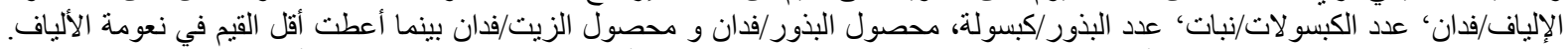

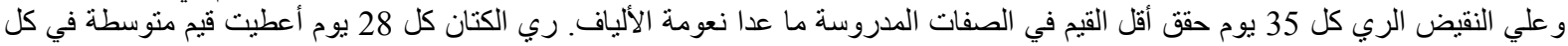

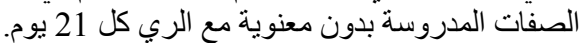

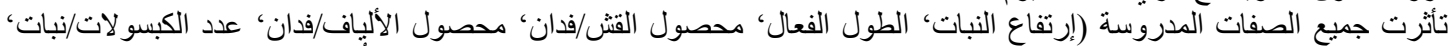

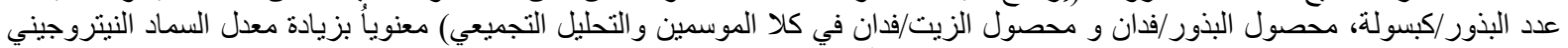

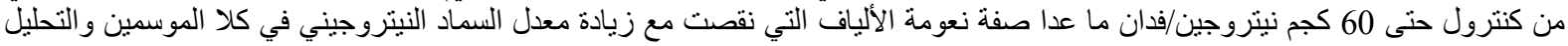

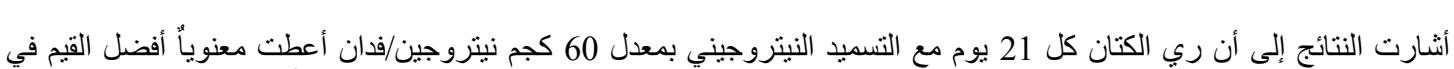

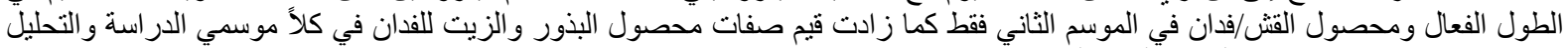

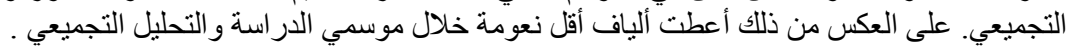

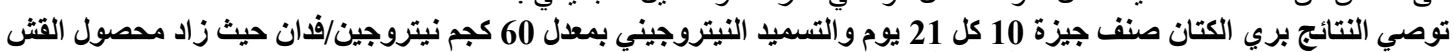

$$
\begin{aligned}
& \text { والبذور بوحدة التمساحة والصفات المرتبطة بهان كماً ونوعاً. }
\end{aligned}
$$

